\title{
Vernakularisme, Informalitas, dan Urbanisme: Café sebagai Ekspresi Gaya Hidup Kontemporer
}

\author{
R.R. Dhian Damajani \\ Program Studi Arsitektur, \\ Sekolah Arsitektur, Perencanaan, dan Pengembangan Kebijakan, \\ Institut Teknologi Bandung, Indonesia \\ Email: ddamajani@yahoo.com
}

\begin{abstract}
The word café originated from coffee, which is commonly used to describe a place where one drinks coffee, i.e. coffeehouse. Generally, this place is not too large in space providing drinks and snacks, as well as accommodates other activities for use either in the morning or late afternoon. This habit of coffee-drinking is carried out by societies in various countries around the world, including in Indonesia. This research explores cafés that embed to the local context of Bandung as case studies. This is due to the increase number of cafés in Bandung during the early 2000s which demostrate conditions that are unique and perhaps unfounded in other places of Indonesia. There are 5 (five) design variables that illustrate the diversity of cafés in Bandung: (1) Scale (café dimensions), (2) Class (low, medium, high economic-level), (3) Type (internetcafé, bookstore-café, music-café, gallery-café etc), (4) Location (part of a commercial area, in one's front yard, along the street, within a public open space), as well as (5) Time (morning, afternoon, late afternoon, evening, or more than one period of time). It is found that cafés in Bandung have developed beyond the boundaries of their origin and denotative meanings. Their existences have become part of the everyday life of the society, it serves not only as a place to chat and spend free time during late afternoons, but also as transactionalspaces that accommodate diverse activities. Referring to Barbara KirschenblattGimblett [1] this situation illustrates the phenomenon of urban vernacularism that is marked by the following characteristics: sporadic, self produced, absence of author and creator identity, as well as free from any formal pressure.
\end{abstract}

Keywords: café; contemporary; life-style; urban-informality; vernacular.

\section{$1 \quad$ Pendahuluan}

\subsection{Globalisasi dan Gaya Hidup (Life-Style)}

Globalisasi yang dampaknya mulai dirasakan pada akhir abad 20, telah melanda hampir seluruh belahan dunia, termasuk Indonesia. Gejala ini merupakan gelombang/arus pertukaran dan kondisi saling mempengaruhi yang memiliki berbagai dimensi: ekonomi, politik, sosial, teknologi, dan budaya. Wilayah urban adalah area yang mendapatkan pengaruh sangat besar. Di Indonesia, 
menjamurnya pusat perbelanjaan, industri mode atau fashion, berkembang pesatnya industri properti, bermunculannya kawasan hunian mewah, termasuk industri kuliner dan gencarnya iklan yang mempromosikan berbagai gaya hidup baru, memperlihatkan betapa kuatnya pengaruh globalisasi ekonomi dan transformasi kapitalisme konsumsi terhadap sebagian besar masyarakat, khususnya di daerah urban. Salah satu pengaruh yang sangat penting dan memiliki dampak sangat signifikan adalah berubah atau bergesernya cara hidup masyarakat urban. Dengan adanya berbagai perubahan seperti: 1) bergesernya perumahan ke arah tepian kota sehingga menjauh dari tempat kerja, 2) terbatasnya waktu yang "tersisa" karena sebagian besar "terserap" oleh kegiatan bekerja, 3) semakin padatnya lalu lintas yang berakibat pada semakin lamanya waktu tempuh dari dan menuju tempat kerja, serta perubahan lainnya telah mengubah ritme dan keseharian masyarakat dalam berkehidupan. Salah satunya adalah kebutuhan untuk bersosialisasi dalam komunitasnya.

Jika sebelumnya, rumah merupakan tempat penting untuk memenuhi kebutuhan tersebut, dalam waktu tidak lebih dari dua dasa warsa ini perlahan-lahan mulai berkurang perannya dan mungkin saat ini telah digantikan oleh "ruang publik alternatif" yang muncul akibat berubahnya gaya hidup (life-style [2]). Saat ini terdapat banyak tempat berkumpul baik untuk kepentingan keluarga, bisnis, pertemanan, ataupun sekedar untuk bertemu. Beberapa di antaranya adalah: restoran, pusat perbelanjaan, taman, square/alun-alun, termasuk "tempat ngopi" yang lebih lazim disebut dengan café (kafe). Budaya bertemu di café ini begitu mudah diterima oleh masyarakat di kota-kota besar di Indonesia, termasuk di Bandung. Beberapa hal yang melatarbelakanginya antara lain: 1) kuatnya ikatan sosial (bukan individualistik) yang telah berakar kuat dan mendasari sifat alamiahnya, 2) dengan iklim tropis yang hangat dan tidak terlalu kering, kebiasaan berkegiatan di ruang luar (di ruang terbuka/tidak berada dalam bangunan) telah dilakukan sejak lama. Dengan demikian, sebetulnya kegiatan ini bukanlah hal yang sama sekali baru karena sudah dilakukan sejak dahulu, namun kini memiliki bentuk dan situasi yang berbeda.

\subsection{Kota Kreatif dan Thirdspace}

Wacana tentang Kota Kreatif (Creative City) merupakan topik hangat yang sangat diminati sejak era ekonomi berbasis industri berakhir. Keterbatasan sumber daya alam menjadi salah satu faktor pendorong penting yang mengalihkan perekonomian menjadi berkiblat pada sumber daya manusia. Beberapa diskusi tentang Budaya Kreatif (Creative Culture) dan Kota Kreatif [3] pada dasarnya menunjukkan adanya perubahan mendasar terhadap cara pandang terhadap kota. Kota yang sangat canggih, sangat teratur, mekanistik dan cenderung steril sehingga menjadikan manusia sebagai "robot-robot" yang terdikte oleh sistem, ternyata bukanlah tujuan akhir yang ingin dicapai sebuah 
kota. Kota yang "hidup", "memiliki ruh", dan memberi "ruang" pada masyarakatnya untuk dapat "mengekspresikan" diri dalam batasan-batasan tertentu, menjadi cita-cita baru yang disadari dunia era pasca-modern.

Hal ini sejalan dengan apa yang dikemukakan oleh Lefebvre [4] tentang pentingnya memunculkan "ruang-ruang sosial" yang secara alamiah dibentuk oleh masyarakat. Lefebvre menyebutnya sebagai ruang representasional (representational space); sementara Soja [5] menyebutnya dengan Thirdspace. Ruang-ruang tersebut adalah ruang yang "diproduksi/dikonstruksi" secara sosial. Terlepas dari penilaian baik-buruk atau legal-illegal, dalam konteks Indonesia, ruang-ruang di "wilayah" ini banyak dilakukan oleh masyarakat yang beraktivitas di sektor informal. Festival-festival temporer, pasar-pasar kaget, termasuk café dan restoran jalanan adalah beberapa contoh di antaranya.

\subsection{Bandung sebagai Kota Kreatif}

Kota Bandung telah lama dikenal memiliki berbagai potensi sumber daya manusia yang berbasiskan seni dan budaya. Musik, tarian, kuliner, kriya, fashion, arsitektur, grafis dan beragam bidang lainnya selalu menjadikan Bandung terus berubah "wajah" sesuai dengan irama jaman. Setiap masa memiliki bentuk yang berbeda. Dalam beberapa tahun terakhir, khususnya era pasca krisis, Bandung seakan "hidup" dan "bangkit" dengan mekanismenya sendiri yang dibangun secara alamiah. Masyarakat "bergerak" mencari "celahcelah" kegiatan perekonomian yang dapat dijadikan mata pencaharian baru. Menjamurnya Factory Outlet (FO), Distribution Stores (Distro), Warung Internet (warnet), Butik, Galeri, Restoran dan Café dengan banyak kelas, Rumah-Rumah produksi, home-industry berbagai jenis makanan, pakaian, cindera mata serta beragam kegiatan lainnya, menunjukkan sebuah "gerakan" yang disebut Florida (dalam Soemardi [6] \}sebagai creative-class.

Keseluruhan kegiatan ini tentu saja memerlukan "wadah/ruang" yang berada dalam konteks dan waktu tertentu. "Komunitas" yang terbentuk pada gilirannya akan memilih ruang mana yang dianggap tepat untuk melakukan aktivitas tersebut. Hal ini memunculkan persoalan yang tampaknya belum diantisipasi oleh kota. Peraturan seperti larangan berjualan di ruang terbuka, diubahnya pasar-pasar dengan bangunan berlantai banyak, sudah tidak relevan lagi dan perlu ditinjau ulang. Demikian halnya dengan peraturan-peraturan yang tidak kontekstual dengan berubahnya paradigma dalam melihat dan memahami sebuah kota. 


\section{Café: Dulu dan Sekarang}

Secara terminologis, kata café berasal dari coffee, yang berarti kopi. Kopi dikenal sebagai salah satu jenis rempah yang menjadi salah satu minuman favorit berbagai bangsa di dunia, termasuk Indonesia. Tradisi minum kopi ini pada umumnya merupakan salah satu kegiatan selingan di antara kegiatan makan utama. Saat minum kopi, biasanya terdapat juga penganan kecil atau ringan sebagai penyerta. Di beberapa kota di Indonesia, kebiasaan minum kopi juga telah dikenal sejak lama. Seperti misalnya di Aceh, kota-kota di Jawa Tengah dan Jawa Timur, juga di Jawa Barat, termasuk Bandung. Kedai kopi telah lama merupakan salah satu tempat yang ramai dikunjungi baik pada pagi ataupun sore hari oleh masyarakat pedesaan.

\subsection{Pergeseran Fungsi Café}

Dalam konteks masa kini, kedai kopi mengalami pergeseran, bahkan perubahan fungsi yang sangat signifikan. Tempat ini tidak hanya sekadar tempat minum kopi namun telah menjadi ruang publik alternatif yang memiliki beragam fungsi. Berbagai kegiatan seperti: pertemuan-pertemuan keluarga, pertemuan bisnis, pertemuan politis, termasuk acara-acara sosial-budaya lainnya, kerap diadakan di tempat ini. Dengan keberagaman ini, kondisi café juga mengalami perubahan. Salah satu contohnya adalah Café Bali, Bandung. Meskipun namanya tetap café, namun tempat ini juga menyediakan berbagai minuman lain, seperti berbagai jenis teh, minuman buah segar (jus), soft-drink, termasuk minuman tradisional Jawa Barat, seperti bandrek dan bajigur. Yang lebih menarik adalah, café ini tidak hanya menyediakan makanan ringan, melainkan makanan "berat", seperti nasi dan lauk pauknya, bahkan dari berbagai daerah termasuk makanan Eropa (steak, dan lain-lain).
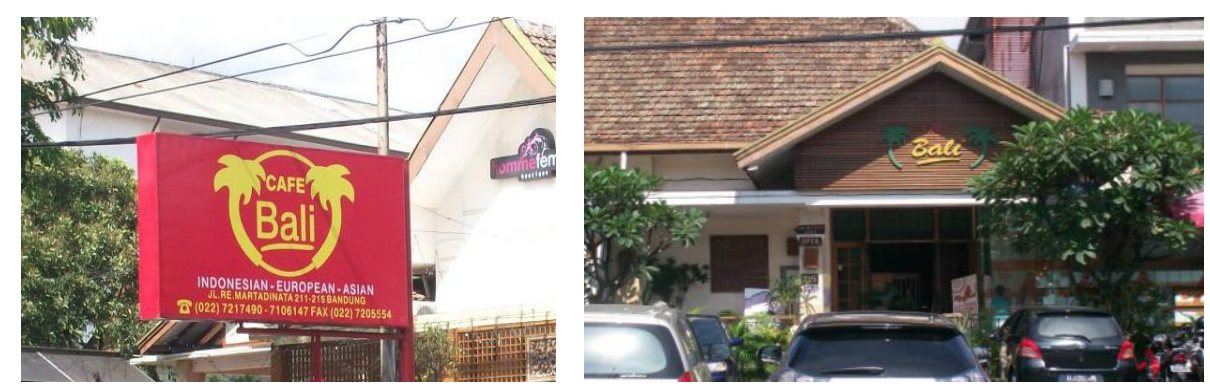

Gambar 1 Café Bali, Jl. RE Martadinata, Bandung; tidak hanya menyediakan kopi dan teman minum kopi melainkan juga makanan berat dari berbagai daerah, termasuk makanan Eropa. 


\subsection{Keberagaman waktu pelayanan}

Café atau kedai kopi pada awalnya merupakan tempat-tempat yang dikunjungi pada saat-saat tertentu saja; khususnya pagi hari sebelum hingga waktu kerja dimulai dan sore hari saat waktu kerja usai. Namun sekarang, waktu pelayanan café juga mengalami perubahan mendasar. Sebagian besar ramai dikunjungi tidak hanya pada pagi dan sore hari, namun selama rentang waktu jam kerja berlangsung. Bahkan café-café tertentu melayani hingga 24 jam, seperti Café Starbucks dan Café Olala.

Salah satu faktor pendorong utama yang menyebabkan sebuah café membuka waktu pelayanannya hingga 24 jam adalah, sifat dari kehidupan urban yang relatif terus berlangsung tanpa henti. Pada bagian tertentu, kegiatan kota berlangsung selama dua puluh empat jam secara bergiliran dan kesempatan ini ditangkap oleh pengelola café sebagai salah satu potensi pasar yang dapat diserap. Karena itulah, bagi sebagian kalangan, café adalah sebuah tempat yang tidak hanya berfungsi untuk tempat melakukan kegiatan, namun telah menjadi bagian dari kehidupan keseharian; sebuah tempat alternatif yang dapat diakses kapan saja.


Gambar 2 Café Olala, Jl. Ir. H.Djuanda, Bandung; beroperasi tidak hanya dalam rentang waktu tertentu, melainkan sepanjang hari selama 24 jam.

\subsection{Jenis Café (internet café, café-toko buku, music-café, galeri- café, dll)}

Café pada awalnya juga dikenal sebagai coffee-shop; sebuah tempat yang relatif kecil karena hanya menjual penganan ala kadarnya sebagai teman minum kopi. Namun saat ini, didirikannya café ternyata juga terkait dengan aktivitas lain yang diwadahinya. Terdapat café yang didukung oleh pelayanan penyediaan internet, yang dikenal dengan internet café. Juga terdapat café yang dibangun 
untuk mendukung keberadaan toko buku yang dikenal dengan bookstore-café. Selain itu, dikenal pula galeri-café, music-café termasuk yang dibangun oleh stasiun radio tertentu.
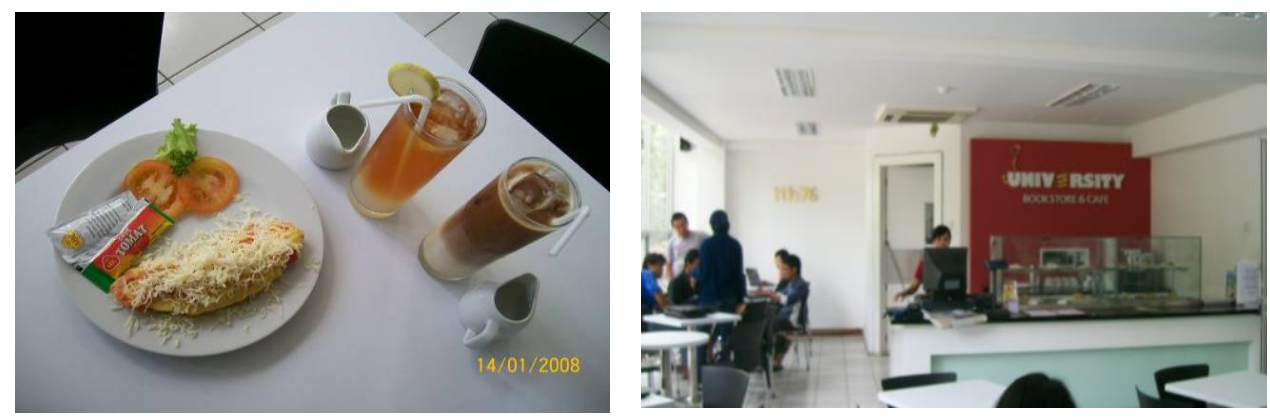

Gambar 3 University Bookstore \& Café, ITB - Bandung.

Terdapat pula café yang secara operasional mandiri, namun keberadaannya tidak terlepas dari fungsi atau aktivitas yang berada di sekitarnya. Seperti cafécafé yang berada di sekitar area Factory Outlet atau distro-distro yang pertumbuhannya relatif sangat cepat di Bandung. Café Ngopi Doeloe termasuk salah satu café yang juga memanfaatkan kebutuhan pelanggan untuk memperoleh fasilitas hot-spot (Wi-Fi). Ketiga cafénya yang terletak di Jl. Hasanudin, Jl. Banda, dan Jl. Teuku Umar hampir selalu ramai dikunjungi oleh berbagai kalangan, khususnya mahasiswa dan kaum muda lainnya dan sebagian tertarik karena café tersebut menyediakan fasilitas layanan internet gratis. Faktor utama ini mendorong aktivitas lain yang muncul kemudian, seperti kebutuhan akan tempat untuk diskusi, pertemuan-pertemuan informal atau sekedar untuk mengobrol dan mengisi waktu luang sehabis kerja.
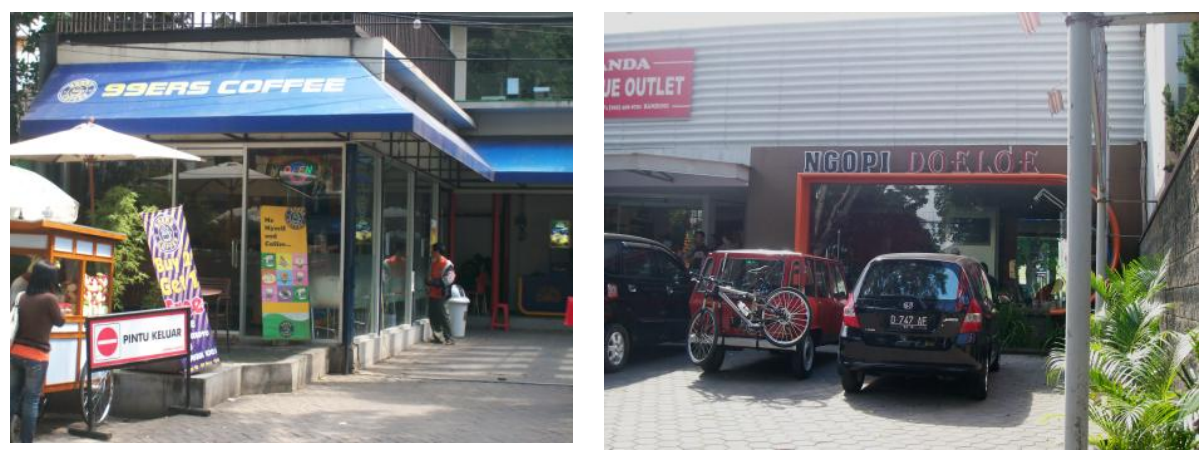

Gambar 4 Café 99ers dan Café Ngopi Doeloe.

Beberapa jenis café lain yang banyak muncul di Bandung sebagai dampak ikutan dari adanya aktivitas utama adalah café yang terletak di sekitar Factory Outlet, seperti yang terdapat di sepanjang Jl. RE Martadinata. Bangunan- 
bangunan semi permanen dengan luas kurang lebih $20 \mathrm{~m} 2$ (berukuran sekitar 3 X 6 meter) pada umumnya didirikan di salah satu sisi halaman FO, seperti diperlihatkan pada Gambar 5 berikut. Kegiatan belanja, baik yang dilakukan oleh perorangan, keluarga, atau rombongan telah memicu kebutuhan untuk makan, baik makan ala kadarnya maupun makan "agak berat" dalam waktu yang relatif singkat. Penyajian yang cepat dan mudah diperoleh menjadi kunci ramainya tempat-tempat makan ini yang sebagian menggunakan kata café.
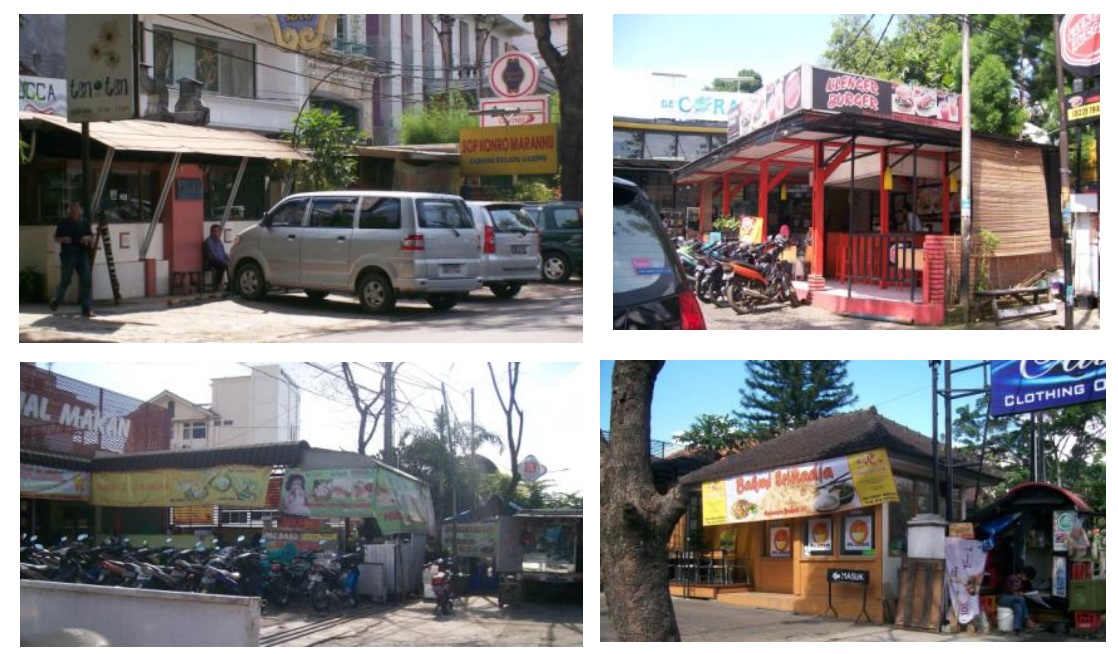

Gambar 5 Kedai-kedai yang dibangun di salah satu sisi halaman bangunan FO untuk menunjang kegiatan utama berbelanja.

Beragam jenis minuman dan makanan disediakan dengan cara yang sangat praktis dalam kemasan yang memikat; sangat mudah diperoleh dengan harga yang relatif terjangkau dan dapat dinikmati di tempat atau dibawa sambil berbelanja. Hal ini merupakan potensi sekaligus menjadi permasalahan spasial yang banyak ditemui di berbagai bagian di Kota Bandung.

Jenis café lain yang muncul karena didorong oleh adanya aktivitas utama lain adalah café yang berada di sekitar lapangan olah raga. Di Kota Bandung terdapat beberapa lapangan olah raga yang hampir selalu ramai dikunjungi sehingga aktivitas kesehariannya memunculkan café-café yang sebagian beroperasi pada pagi hari, siang hari atau sore hari; bahkan ada pula yang beroperasi di sepanjang hari kerja. Tiga area yang diamati dalam penelitian ini yaitu: di sekitar kompleks olah raga Sabuga (Sasana Budaya Ganesa), lapangan olah raga Gelora Saparua, dan Lapangan Gasibu, seperti diperlihatkan pada gambar-gambar berikut. 

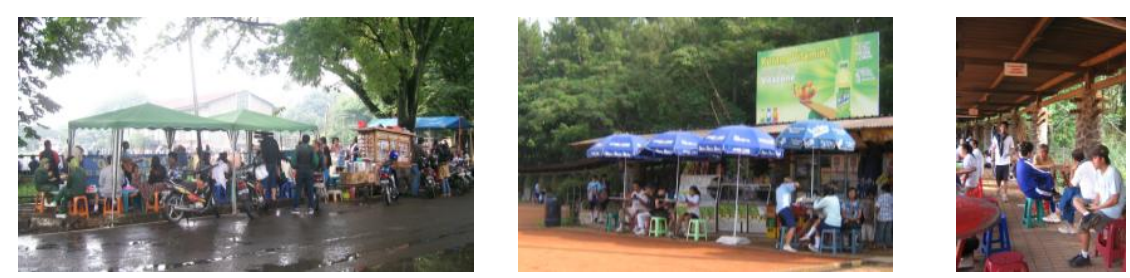

Gambar 6 Café di sekitar lapangan olah raga Gelora Saparua (kiri) dan Kompleks Olah Raga Sabuga (tengah - kanan).

Keragaman café seperti telah diuraikan di atas dapat dikelompokkan berdasarkan skala, kelas, jenis, letak dan waktu dalam Tabel 1 berikut ini.

Tabel 1 Keragaman café di Kota Bandung Tahun 2008.

\begin{tabular}{ll}
\hline \multicolumn{1}{c}{ Variabel } & \multicolumn{1}{c}{ Kategori/contoh } \\
\hline Skala & Kecil (kapasitas maksimal 6 orang) \\
& Sedang (kapasitas maksimal 20 orang) \\
& Besar (lebih dari 20 orang) \\
Kelas & Murah \\
& Sedang \\
& Mahal \\
& Bookstore-Café, Internet-Café, Galeri-Café \\
Jenis & Music-Café, Distro-Café, FO-Café, \\
& Café-Tenda \\
& berdiri sendiri, menjadi bagian dari area komersial \\
Letak & di halaman rumah, di tepi jalan, di trotoar \\
& di dalam area ruang terbuka publik \\
& dini hari, pagi hari, siang hari, sore hari, malam hari \\
Waktu & lebih dari satu rentang waktu \\
Pelayanan & 24 jam \\
\hline
\end{tabular}

\section{Café Tenda: Vernakularisme dan Informalitas Urban}

Salah satu jenis café yang menjadi objek pengamatan lebih dalam adalah cafécafé yang sehari-hari beraktivitas di ruang terbuka publik, seperti di sekitar lapangan olah raga dan di area jalur pejalan kaki khususnya trotoar yang berada di sekitar pusat-pusat kegiatan. Keberadaan café-café ini di satu sisi sangat diperlukan untuk menunjang aktivitas keseharian masyarakat, namun di sisi lain menimbulkan persoalan spasial tata ruang kota yang sangat serius. Pada umumnya beraktivitas pada jam-jam tertentu (tidak permanen) dan menggunakan naungan (shelter) berupa tenda bongkar pasang, sehingga disebut dengan café-tenda.Sebagian memanfaatkan lalu lalang pejalan kaki yang beraktivitas di sekitar fasilitas komersial, sebagian memanfaatkan ruang kota 
yang tampak "tak bertuan" (brandgang, area "hijau" di persimpangan trotoar) dan sebagian yang lain menggunakan seluruh badan trotoar bahkan ada pula yang memanfaatkan badan jalan, seperti terlihat pada Gambar 7 .

Melalui penelitian ini, diungkapkan 3 (tiga) kasus studi café-tenda, yaitu: (A) Café Madtari yang beraktivitas di trotoar Jl. Dipatiukur, (B) café-café di sekitar Kampus Universitas Padjadjaran yang beraktivitas di trotoar Jl. Hasanudin, dan (C) café Choice yang beraktivitas di trotoar sekitar Lapangan Gasibu.
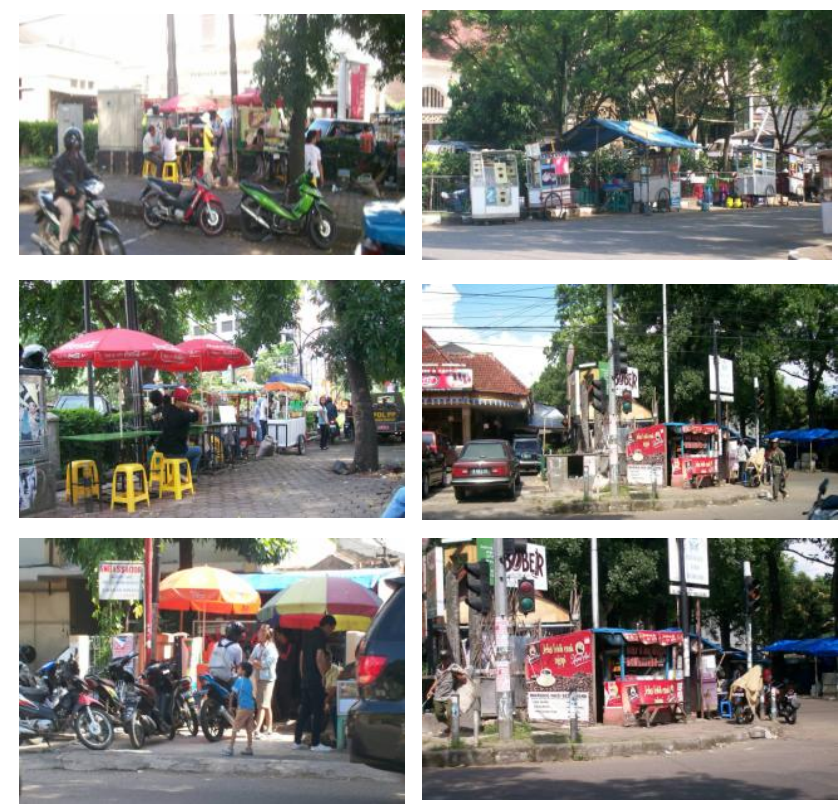

Gambar 7 Café-Tenda yang beraktivitas di beberapa area ruang terbuka publik.

\subsection{Café Madtari}

Café ini didirikan oleh Faezi Madtari yang berasal dari Tasikmalaya, Jawa Barat sekitar tahun 1997-1998 ketika krisis ekonomi menerpa Indonesia. Sebelumnya beraktivitas di Jl. Ir H. Djuanda, di dekat persimpangan Jl. Surapati. Sekira tahun 2006, area tersebut "ditertibkan" dan aktivitas informal yang sebelumnya banyak terdapat di sepanjang jalan tersebut, harus dibersihkan. Sejak saat itu Café Madtari berpindah ke Jl. Dipatiukur yang "ditempatinya" sekarang tanpa ditinggalkan pelanggannya.

Saat ini operasional café dilakukan oleh 12 orang pegawai. Mereka mulai menyiapkan tenda sejak pk.14.00 untuk melayani pelanggan yang sebagian besar merupakan kaum muda. Café mulai buka sekitar pk. 16.00 hingga dini 
hari pk.03.00. Pada umumnya, café mulai dipadati sejak pk. 17.30 petang. Sedangkan hari-hari padat pengunjung biasanya adalah hari Jumat, Sabtu, Minggu dan Senin. Terdapat 3 meja yang dapat ditempati oleh 8-10 orang dan 9 meja berukuran lebih kecil, cukup untuk 4-5 orang. Jadi, saat penuh café ini dapat memuat sekitar 60 hingga 75 orang. Saat tidak digunakan, meja-meja besar dan tenda diletakkan di area tersebut, sedangkan gerobak peralatan, meja kecil dan kursi-kursi, dititipkan di kediaman Ketua RT yang tinggalnya tidak jauh dari tempat ini. Untuk keperluan tersebut, tentu saja ada biaya ijin yang harus dikeluarkan. Namun tidak terdapat informasi mengenai hal tersebut. Berdasarkan wawancara yang dilakukan, diungkapkan bahwa untuk dapat berjualan di tempat tersebut, ada retribusi sebesar Rp 500,- per hari yang dipungut oleh petugas (tidak dijelaskan, petugas apa yang dimaksud).

Menurut sebagian besar pelanggan yang berstatus mahasiswa, salah satu daya tarik café ini adalah harga makanan dan minumannya yang beragam. Menu termurah yaitu kopi panas ( $R p$ 2000,-) dan Indomie Rebus (Rp 2500,-) cukup membuat perut terasa kenyang. Menu favoritnya adalah indomie goreng telurkeju-kornet seharga Rp 10.000,- dan roti bakar dan pisang bakar-keju. Suasana saat café belum terlalu padat, juga dapat dilihat pada gambar ini.
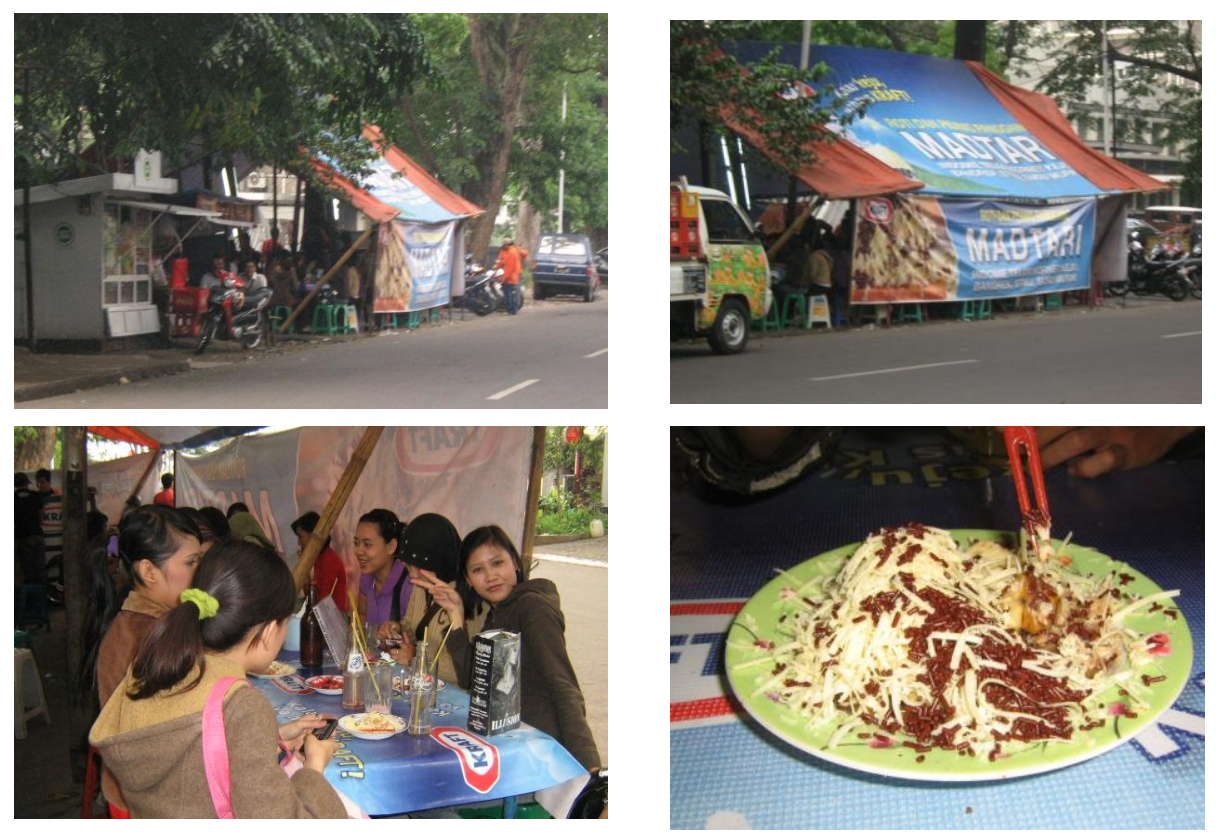

Gambar 8 Café-Tenda Madtari di Jl. Dipatiukur, Bandung. 


\subsection{Café-café Tenda di Sekitar Kampus Universitas Padjadjaran, Jl Hasanudin, Bandung}

Kampus Universitas Padjadjaran merupakan salah satu kampus urban di Kota Bandung yang sejak awal berdirinya menempati area di persimpangan $\mathrm{Jl}$. Dipatiukur dan Jl. Hasanudin. Meski sebagian besar kegiatan kampus telah beralih ke area kampus di wilayah Jatinangor, Kabupaten Bandung, sebagian kegiatan masih berlangsung di sini. Kegiatan keseharian yang berlangsung secara terus menerus (di luar hari libur), telah memicu berdirinya café-café tenda dalam jumlah yang sangat signifikan, seperti terlihat dalam Gambar 9 berikut. Café-café ini tidak hanya menyediakan makanan dan minuman ringan, melainkan juga menu makan siang, bahkan beberapa di antaranya beroperasi hingga malam hari. Kebutuhan ini didorong oleh sebagian besar mahasiswa yang tinggal di kamar sewa (kost), tanpa fasilitas makan.

Saat penelitian dilakukan, terdapat café-café yang berada di trotoar sepanjang lebih dari 110 meter dengan jumlah lapak (booth) lebih dari 40. Seperti tampak dalam gambar, area yang sangat terbatas ini, mendorong pula adanya kebutuhan lain, yaitu area parkir (baik motor maupun mobil) yang menggunakan badan jalan secara sangat intensif. Dalam hal ini, perlu dilakukan pendekatan yang tepat dalam melakukan penataan spasial yang sarat dengan persoalan sosialbudaya.
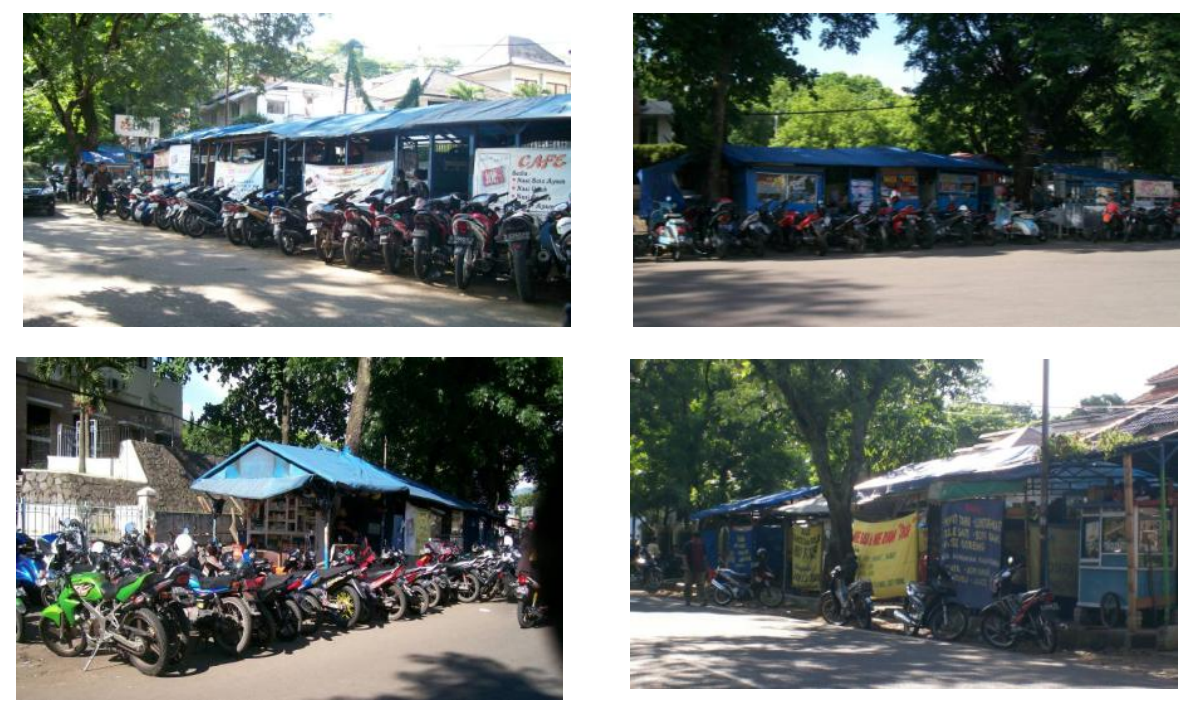

Gambar 9 Café-Tenda di sekitar J1 Hasanudin dan Jl Dipatiukur Bandung. 


\subsection{Café Choice, Lapangan Gasibu Bandung}

Café Choice terletak di trotoar yang berada di sisi Barat Lapangan Gasibu. Café ini beroperasi sejak sore hari pk.16.00 hingga pagi hari. Kegiatan sore dan malam hari yang dilakukan oleh sebagian warga, terutama kaum muda, menjadi pelanggan utama café ini.

Susu murni (bukan kopi), justru menjadi menu favoritnya. Terdapat 13 varian susu berbagai jenis rasa (buah, dilengkapi telor, madu, jahe, bandrek, dll) yang kadang tidak dijumpai di tempat lain. Harga yang relatif terjangkau (Rp 3500,-) untuk segelas susu murni dan berbagai menu roti bakar dan mie instant (Rp 3500,-) menjadikan café ini ramai dikunjungi, terutama pada malam Jumat, malam Sabtu, dan malam Minggu. Keistimewaan lain area ini adalah sejak sekira awal tahun 2000an, area Gasibu dan sekitarnya menjadi tempat berlangsungnya pasar minggu hingga saat ini.
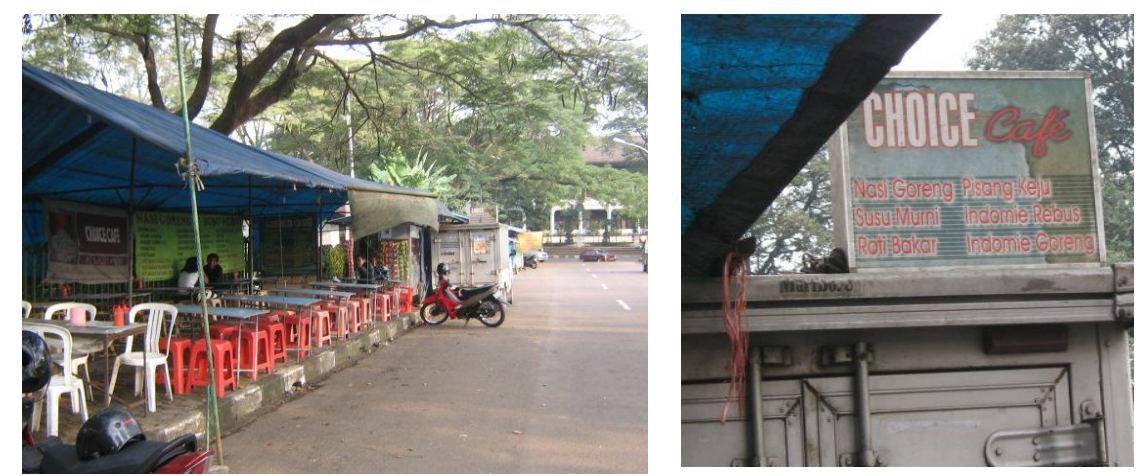

Gambar 10 Café Choice di sekitar Lapangan Gasibu, Bandung.

Beragamnya café dalam jumlah dan ragam isi serta suasananya menunjukkan tingginya potensi warga Bandung dalam memunculkan gagasan-gagasan baru tentang cara memproduksi ruang publik, khususnya dalam pengertian ruang ketiga (thirdspace). Gejala Ruang Ketiga (Thirdspace) merupakan salah satu kerangka lain dalam memahami gejala spasialitas yang dikemukakan oleh Edward Soja. Gagasan ruang ini merupakan kategori ruang lain, yang memungkinkan untuk diinterpretasikan tanpa batas; ruang yang bergerak di antara real-and-imagined yang dibentuk oleh kekuatan-kekuatan yang ada dalam masyarakat.

Damajani [7] menyatakan bahwa salah satu karakteristik umum ruang ketiga di Kota Bandung adalah adanya Kesatuan Ruang-Waktu-Aktor.

Ruang sebagai unsur spasial yang mewadahi berlangsungnya kegiatan, secara fisik (materi) pada dasarnya tetap. Elemen-elemen pendukungnyalah yang berperan mengubah tata letak/susunan/komposisi sehingga ruang tersebut memiliki beragam 
bentuk dan suasana yang berbeda-beda. Demikian halnya dengan waktu, yang juga bersifat dinamis. Yang dimaksud dengan dinamika waktu di sini adalah, bagaimana peran waktu yang "seolah-olah" mengatur, mengendalikan, bahkan menentukan kapan suatu peristiwa harus atau sebaiknya diselenggarakan. Suatu kegiatan harian, mingguan, bulanan, atau tahunan yang mewarnai kehidupan keseharian, akan berbeda-beda bergantung masyarakat pendukungnya; apakah dalam tingkatan lingkungan, bagian kota, atau kota. Aktor sebagai aspek lain yang berperan utama dalam memaknai sebuah ruang (space) menjadi sebuah tempat (place), juga merupakan unsur yang menentukan dalam pembentukan sebuah peristiwa. Seperti halnya ruang dan waktu, aktor juga bersifat dinamis. Yang dimaksud dengan dinamika aktor di sini adalah: (1) secara individu memiliki tingkat mobilitas yang tinggi di dalam ruang, (2) jika berada di dalam kelompok dapat berpindah-pindah sesuai dengan situasi dan kondisi tertentu, (3) masing-masing aktor (baik secara perseorangan maupun kelompok) dapat berubah peran sesuai dengan konteks yang menyertainya.

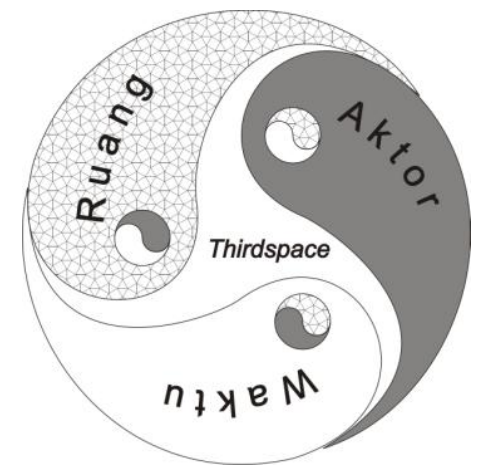

Gambar 11 Kesatuan R-W-A (Ruang-Waktu-Aktor).

Café tenda dapat dikategorikan sebagai ruang ketiga. Keberadaannya bersifat tidak permanen; yang dibentuk oleh aktivitas aktor melalui penguasaan terhadap ruang-ruang terbuka publik melalui penandaan-penandaan tertentu. Café Madtari, Café Choice dan café-café yang beraktivitas di sekitar Kampus Universitas Padjadjaran menunjukkan bagaimana ruang ketiga diproduksi melalui aktivitas keseharian dan menjadi ruang sosial alternatif yang secara spasial terjadi di trotoar.

Karakteristik umum kedua fenomena ruang ketiga di ruang publik Kota Bandung adalah adanya fleksibilitas batas, baik ruang maupun waktu. Yang dimaksud dengan batas ruang di sini adalah batas ruang fisik (spasial) yang digunakan sebagai wadah spasial dalam melakukan kegiatannya. Sedangkan yang dimaksud dengan batas waktu adalah rentang waktu yang diperlukan selama kegiatan berlangsung ketika ruang ini terkonstruksi. Fleksibilitas batas ruang-waktu yang dimaksud di sini adalah dinamika yang terjadi, baik secara me-ruang maupun me-waktu, yang berpengaruh terhadap terkonstruksinya 
ruang ketiga pada setiap peristiwa. Dalam konteks kasus studi café, secara spasial, komposisi dan tata letak ruang ketiga dikonstruksi oleh unsur-unsur bersifat fleksibel. Unsur pembentuk ruang secara fisik, pada umumnya berupa lapangan atau trotoar sebagai lantainya, keteduhan pepohonan atau naungan berupa tenda sebagai pembatas atasnya, dan pemanfaatan dinding bangunan atau pagar sebagai pembatas vertikal jika diperlukan. Pembagian waktu: pagi, siang, sore, dan malam juga turut menentukan kategori café dan suasana yang dibangunnya.

Selanjutnya, Damajani [7] juga menyatakan bahwa terdapat tiga paradoks yang terdapat dalam praktik penggunaan ruang publik di Kota Bandung, yaitu (1) paradoks antara informalitas dan formalitas, (2) paradoks antara ruang publik dan privat, serta (3) paradoks antara fenomena keteraturan (order) dan kekacauan (chaos). Isu informalitas dan formalitas yang hampir selalu muncul bersamaan dalam setiap bentuk gejala ruang ini. Tarik menarik keduanya sering menimbulkan persoalan sosial-budaya yang sangat serius, namun dalam konteks positif merupakan kekuatan yang dapat menjadi daya hidup sebuah kota. Dalam konteks kasus studi café, diperlihatkan bagaimana keberadaan café tenda yang saat ini termasuk dalam kategori kegiatan sektor informal berada dalam situasi spasial yang bersifat formal. Peraturan kota yang bersifat formal, khususnya yang mengatur fungsi-fungsi seperti jalan, trotoar, ruang terbuka, dalam konteks ini berhadapan dengan kegiatan keseharian warga kota yang sudah selayaknya dapat dipenuhi.

Paradoks kedua yaitu persoalan ruang privat dan publik. Adanya fleksibilitas batas baik batas ruang maupun batas waktu, memunculkan penggunaan ruang yang saling silang, saling tumpuk, serta lintas batas dalam praktik kehidupan keseharian di ruang kota. Dalam banyak peristiwa, fleksibilitas ini menjadi alternatif solusi dalam memenuhi kebutuhan ruang publik secara temporal. Hal ini juga diperlihatkan melalui praktik-praktik spasial yang bersifat temporer, termasuk yang terjadi pada kasus studi café. Trotoar yang bersifat publik pada waktu-waktu tertentu dapat menjadi "area privat temporer" yang penggunaannya dapat diatur sesuai dengan kebutuhan. Potensi masyarakat dalam menyiasati berbagai kebutuhan sekaligus persoalan keseharian ini, sebaiknya dipertemukan dalam sebuah tatanan yang bertujuan mengharmonikan keduanya.

Paradoks ketiga adalah fenomena keteraturan (order) dan kekacauan (chaos). Keteraturan yang dimaksud di sini bukanlah berupa struktur yang kaku (rigid) dan bersifat mekanistik, melainkan suatu jejaring (networking) yang terdiri dari kekuatan-kekuatan banyak aktor yang satu sama lain saling mempengaruhi. Dalam banyak peristiwa, hal ini merupakan fenomena yang menggambarkan hakikat persoalan yang dikandungnya. Salah satu karakter uniknya adalah 
bahwa selalu terdapat keteraturan tersembunyi (hidden order) di balik bentuk permukaannya yang terlihat kacau (chaos). Bentuk keteraturan (sistem) yang pada awalnya bersifat sederhana ini secara alamiah akan terus berkembang dan berubah mengikuti perubahan yang terjadi. Dalam kasus studi café, terlihat bahwa terdapat jejaring yang melibatkan terkonstruksinya café dengan komunitasnya. Para aktor yang terlibat, seperti: pemilik café, institusi lokal/pengelola area, warga di sekitar lokasi, termasuk pemerintah kota dan penyandang dana dan pengampu kepentingan lain (stake-holder) dapat membuat kesepakatan-kesepakatan yang bertujuan untuk mempertemukan berbagai kepentingan tanpa mengorbankan pihak yang lain.

Pandangan ruang ketiga yang mengakui keberadaan seluruh praktik produksi spasial dan keberagaman persoalan nyata (real) tanpa menganggap yang satu lebih penting dari yang lain; menghendaki suatu tatanan harmoni yang mempertemukan berbagai kompleksitas yang terdapat di dalamnya. Penataan area-area tersebut sebaiknya didasari oleh pendekatan persoalan yang memandang sosial-budaya sebagai bagian penting dalam penataan kota secara spasial. Secara singkat, ketiga aspek penataan dapat dijabarkan sebagai berikut:

Aspek Pertama: Multi Ruang

1. memperlebar jalur pedestrian hingga 4-6 meter, sehingga area pejalan kaki dapat berdampingan dengan kegiatan lain yang dapat menghidupkan suasana pedestrian

2. menetapkan area/lokasi yang dapat ditempati oleh café tenda atau kios (tidak di sembarang tempat)

3. café tenda dan kios serta elemen lainnya dirancang khusus sesuai dengan kebutuhan dengan harga yang dapat dijangkau oleh para pelaku kegiatan ini

4. parkir (roda dua atau empat) diatur sehingga kepentingan pengguna jalan lain tidak terabaikan

5. menyediakan tempat-tempat duduk pada beberapa lokasi

6. mewajibkan seluruh pelaku untuk menjaga kebersihan tempat aktivitas dilakukan

Aspek Kedua: Multi Waktu

1. aktivitas yang dilakukan di ruang terbuka publik, termasuk di area pedestrian, tidak berlangsung selama 24 jam

2. penggunaan diatur secara bergiliran melalui mekanisme yang jelas dan terbuka bagi publik

Aspek Ketiga: Multi Aktor

1. diperlukan peran aktif seluruh aktor (pemerintah kota, perencana, warga di sekitar lokasi, para pelaku sektor informal (dalam hal ini pemilik café-tenda, 
pengusaha (bila ada) untuk terlibat dalam penciptaan lingkungan yang aman, bersih dan nyaman baik secara fisik maupun sosial. Masing-masing ditempatkan sesuai dengan peran dan fungsinya sehingga terjadi sinergi yang mampu menggerakkan seluruh potensi yang ada.

2. kesempatan untuk mengakses ruang tersebut diatur secara adil, terbuka bagi siapa pun dengan mekanisme yang jelas dan terorganisasi dengan baik.

Salah satu ilustrasi penataan ruang fisik yang diusulkan tergambar dalam Gambar 12 berikut.



Gambar 12 Ilustrasi usulan penataan fisik area trotoar di sekitar area yang memungkinkan untuk aktivitas café-tenda dan kios. 


\section{$4 \quad$ Penutup}

Kajian tentang ruang publik merupakan persoalan lintas disiplin yang memerlukan kehati-hatian dalam menyikapinya. Kekeliruan dalam mendekati persoalan dan keterbatasan dalam memahami persoalan yang dikandungnya, akan menghasilkan kesimpulan yang berbeda bahkan bertolak belakang. Keberpihakan menjadi salah satu unsur yang akan menunjukkan perbedaan cara pandang masing-masing.

Ruang ketiga sebagai salah satu cara pandang dalam memahami ruang, dalam hal ini - ruang publik, memberikan perhatian khusus pada aspek sosial-budaya. Peran aktor dalam mengkonstruksi ruang (sosial) menjadi aspek penting yang pada akhirnya sangat berpengaruh terhadap kualitas ruang kota yang dikandungnya. Dalam konteks kota Bandung, café sebagai ruang-ruang ketiga yang diproduksi secara sosial ini menjadi salah satu mekanisme adaptasi ekonomi, khususnya era pasca krisis yang dialami pada dasawarsa yang lalu. Fleksibilitas yang dimilikinya merupakan kekuatan yang menjadi daya hidup sebagai upaya penyesuaian diri terhadap berbagai situasi dalam kondisi paling ekstrim sekalipun. Kemungkinan produksi spasial yang tak terbatas ini memunculkan kategori café yang sangat beragam.

Café tenda sebagai salah satu produk dari gaya hidup kontemporer - yang salah satunya dicirikan oleh tergantikannya peran rumah oleh ruang-ruang publik (khususnya di daerah urban)- menjadi ruang publik alternatif yang sangat diminati oleh warga kota. Kebutuhan untuk bersosialisasi, kebutuhan untuk mengisi perut kosong dengan makanan ringan atau bahkan dengan makanan berat, dipenuhi oleh kehadiran café tenda ini. Karena itu, tentu saja keberadaannya perlu dipandang secara positif, meski banyak persoalan yang ditimbulkannya. Kompleksitas persoalan ini perlu dicarikan berbagai alternatif solusinya yang sedapat mungkin mengharmonikan berbagai kepentingan atas dasar kesadaran untuk membuat lingkungan menjadi lebih baik.

Selain itu, dengan terbatasnya jumlah ruang terbuka publik kota dan semakin meningkatnya jumlah penduduk perkotaan maka perlu dipikirkan pendekatan perencanaan yang mempertimbangkan: Multi-Ruang, Multi-Waktu, dan MultiAktor, khususnya dalam merencanakan ruang publik urban. Tidak mungkin lagi ruang-ruang publik urban kita hanya melayani satu fungsi tertentu saja, waktu tertentu saja, apalagi aktor tertentu saja; karena pada hakikatnya publik adalah segala sesuatu yang tanpa sekat, tanpa batas, tanpa hirarki, namun dikendalikan oleh norma dan etika yang mengusung nilai-nilai keadilan, kesejajaran, dan kebersamaan untuk mencapai keharmonisan; meskipun kita menyadari adalah sebuah utopia untuk menjadikan kota berada dalam sebuah keseimbangan yang sempurna baik secara ekologis maupun sosiologis. 


\section{Ucapan terima kasih}

Penelitian ini dibiayai oleh ITB berdasarkan Surat Perjanjian Pelaksanaan Penelitian No: 0024/K01.03/KONTR-WRRIM/PL2.1.5/I/2008, tanggal 15 bulan Januari 2008.

\section{Referensi}

[1] Kirschenblatt-Gimblett, Barbara. 1999. Performing The City: Reflections on The Urban Vernacular dalam Everyday Urbanism, The Monacelli Press inc., New York.

[2] Lihat Chaney, David (terj.). 2003. Lifestyles, Penerbit: Jalasutra, Yogyakarta.

[3] Landry, C. 2000. The Creative City: A Toolkit for Urban Innovator, London: COMEDIA. dan Florida, R. 2002, The Rise of The Creative Class: And How It's Transforming Work, Leisure, Community and Everyday Life, New York: Basic Books.

[4] Lefebvre, Henri. 1991. The Production of Space, Blackwell Publishers Inc., Massachusetts.

[5] Soja, Edward W. 1996. Thirdspace: Journeys to Los Angeles and Other Real-and-Imagined Places, Blackwell Publishers Inc., Massachusetts.

[6] Soemardi, A.R. 2006. Bandung as A Creative City: Visions on Creative Culture and The Making of Place, dalam Soemardi, A.R dan Abadi, A.A (eds.), Proceedings, International Seminar on Urban Culture - Arte-Polis: Creative Culture and The Making of Place, Bandung: School of Architecture, Planning and Policy Development, Institut Teknologi Bandung, pp. VI-158-170.

[7] Damajani, D. 2008. Gejala Ruang Ketiga Thirdspace) di Kota Bandung: Paradoks dalam Ruang Publik Urban Kontemporer (Thirdspace Phenomena in the City of Bandung: Paradox in Contemporary Urban Public Space), Disertasi Doktor, Fakultas Seni Rupa dan Desain, Institut Teknologi Bandung. 